\title{
CÓRREGOS OCULTOS NA CIDADE DE SÃO PAULO: CÓRREGO TIBURTINO NA LAPA
}

\author{
HIDDEN STREAMS IN THE CITY OF SÃO PAULO: TIBURTINO STREAM IN LAPA
}

\author{
Murillo Aggio Piazzi*
}

\section{RESUMO}

Este artigo trata dos córregos ocultos em São Paulo, com ênfase em um caso particular: o córrego Tiburtino. Pretende-se fazer emergir à consciência a existência de cursos d'água naturais vivos, embora ocultos. Para isso, empregaram-se como métodos investigativos: pesquisa cartográfica, visita a campo, consulta de jornais e crônicas de viagens, entre outras fontes, visando ao reconhecimento de algum curso d'água suprimido da paisagem paulistana. Aplicando-se o método mencionado, delimita-se o distrito da Lapa como recorte geográfico, região onde há grande probabilidade de localizar nascentes e córregos. Posteriormente, uma vertente é identificada no bairro conhecido como Vila Ipojuca. A investigação dessa nascente leva à detecção de uma rede de córregos pertencentes a uma bacia hidrográfica que se encontra totalmente velada - a bacia do córrego Tiburtino. Durante a investigação histórica, constata-se que o aproveitamento dos córregos na paisagem foi suprimido em decorrência de processos que deterioraram os cursos d'água, como a ineficiência do estado em estabelecer uma rede eficaz de coleta e tratamento de esgotos. Isto é um problema atual: os córregos estudados exalam forte odor, que denuncia o despejo de esgoto em suas águas. Os trajetos descritos neste artigo remontam o curso que as águas seguiam. Presenciam-se as marcas deixadas pelo córrego no ambiente urbano: vielas, bueiros, odores e até o som do córrego fluindo podem ser notados. No entanto, em raros momentos é possível observar as águas, que continuam correndo anônimas nas entranhas da cidade. Palavras-chave: Córregos. Memória. Paisagismo.

\section{ABSTRACT}

This scientific paper studies hidden streams in the city of São Paulo, emphasizing one specific case: the Tiburtino stream. It intends to reveal the existence of natural, living watercourses in the city, even though hidden. The cartographic research, in situ exploration, and investigation of newspaper clippings and travel chronicles used to this end aim at acknowledging some streams, hidden from the landscape. The district of Lapa, a region where it is more likely to spot springs and streams, is used as the geographical portion for this study. The identification of a spring in a neighbourhood known as Villa Ipojuca comes as a result of this research. The investigation of this spring led to the detection of a drainage system belonging to a completely hidden watershed - called Tiburtino. The historical investigation established that the integration between the streams and the landscape has been supressed due to processes which deteriorate the watercourses, such as the State's inefficiency to build a robust drainage system. This is a current issue, where the studied streams were found to release severely unpleasant odors, which means wastewater is still disposed of in the

\footnotetext{
Universidade de São Paulo, Faculdade de Arquitetura e Urbanismo.

Rua do Lago, 876, CEP 05508-080, Butantã, São Paulo, SP.

CV: http://lattes.cnpq.br/0595080042222717

murijo@gmail.com
} 
water. The paths presented in this paper date back to the old course the water used to take. The signs these streams left still remain in the urban landscape: narrow streets, manholes, odors, and even the sound of the flowing streams can be noticed. However, rare moments still allow us to observe as water continues to flow, hidden beneath the city.

Keywords: Streams. Memory. Landscape

\section{INTRODUÇÃO}

O apagamento da memória em relação às formas naturais do sítio de uma cidade, ou seja, a não cidade que existe antes da ocupação urbana, é um fenômeno que tem se intensificado na cidade de São Paulo. Esse processo tem se estabelecido devido ao encobrimento e/ou transformação dos elementos naturais que existem nesse sítio por sucessivas camadas de urbanização. Uma das consequências da não preservação desses traços naturais é a dificuldade de as gerações futuras identificarem a base natural sobre a qual sua cidade foi construída.

O nível atual de urbanização de São Paulo impede que parte da vasta rede de córregos responsável por esculpir o relevo de seu sítio urbano seja visível. Apenas um grupo restrito e cada vez menor de pessoas pôde ter contato com córregos quando ainda não estavam canalizados. Esse grupo ainda possui na memória os signos que representam os córregos, sejam eles diretos, quando o curso d'água ainda fazia parte da paisagem cotidiana, ou ainda indiretos, quando se utilizavam de bicas ou tanques. Atualmente, os elementos a partir dos quais é possível presenciar a manifestação de um córrego são signos que passam despercebidos para a maior parte das pessoas bueiros, escadarias, vielas, dutos.

A preservação de nossos corpos hídricos e, sobretudo, de seu valor paisagístico foi normalmente negligenciada. Nascentes foram mudadas de lugar, trajetos naturais foram retificados, brejos foram aterrados, córregos foram canalizados e, por cima da canalização, construíram-se avenidas. Desse modo é cada vez mais difícil que os córregos permaneçam na memória coletiva da população. Existe a possibilidade que essa memória seja totalmente apagada no futuro.

Por esse motivo, a intenção deste estudo é trazer à superfície os elementos que provam a existência desses córregos e registrá-los, para que as gerações do presente e do futuro possam construir a própria memória desses cursos d'água, antes que as sucessivas camadas de urbanização apaguem totalmente os últimos vestígios da existência da vasta rede hidrográfica de São Paulo. Assim, cria-se a possibilidade de que os córregos ocultos, uma vez identificados, possam receber futuras intervenções, que os reabilitem e qualifiquem, para que sejam reintegrados aos espaços livres públicos e, consequentemente, à apropriação coletiva.

Será apresentado como estudo de caso o córrego Tiburtino, que corre confinado nas galerias subterrâneas do bairro da Lapa. $\bigcirc$ processo de ocultação desse córrego é bastante representativo do modo como os cursos d'água foram aos poucos sendo degradados e suprimidos da paisagem. No entanto, antes mesmo da escolha desse 
córrego como estudo de caso, foi necessário investigar o relevo do território paulistano, identificando como se formam e onde estão localizados os córregos da cidade.

\section{EM BUSCA DAS NASCENTES}

A paisagem urbana de São Paulo, formada por diversas camadas de urbanização que se sobrepuseram ao longo do tempo, cria uma espécie de 'segunda natureza'. As linhas primitivas do sítio onde a cidade se instalou foram drasticamente modificadas, de modo que se torna difícil, até mesmo para um especialista, distinguir certos aspectos topográficos originais.

Devido a essa dificuldade, torna-se ainda mais complicado o trabalho de localização de um córrego canalizado. É necessário recorrer a uma bibliografia específica da geografia para chegar à delimitação de uma área onde há grandes possibilidades de encontrar nascentes. Os termos usados nos livros que investigam a geomorfologia (ciência que estuda os relevos) são muitas vezes incompreensíveis para não especialistas. No entanto, alguns autores desse campo de pesquisa relacionam a ocupação urbana com o tipo de relevo estudado, o que torna sua leitura muito mais atrativa e inteligível para arquitetos e urbanistas. Nesse sentido, a leitura geomorfológica que Ab'Sáber (2007) faz sobre o sítio urbano de São Paulo permite a caracterização de áreas onde nascentes podem ocorrer com maior frequência.

A cidade de São Paulo possui dois grandes rios, Tietê e Pinheiros, que confluem para um ponto em comum, formando assim um ângulo. $\bigcirc$ ângulo interno formado pela confluência abriga a porção da cidade que se desenvolveu majoritariamente até meados dos anos 1970, e que hoje corresponde aproximadamente à área interna do minianel viário denominado 'centro expandido' (figura 1). Essa área abriga elementos topográficos que marcam a paisagem paulistana, como o Espigão Central, onde está situada a avenida Paulista. Segundo Ab'Sáber, os córregos situados no ângulo central caracterizam a topografia do seu entorno da seguinte maneira:

A erosão das vertentes nos altos rebordos do Espigão Central criou uma série de pequenos acidentes de relevo devido ao festonamento excessivo das encostas superiores. [...] as minúsculas e bem marcadas bacias de recepção de águas dos afluentes do Tietê conseguiram retalhar os rebordos do espigão esculpindo diversos tipos de esporões laterais e altas colinas, em processo inicial de isolamento em relação aos estreitos esporões que as vinculam ao divisor principal (AB'SÁBER, 2007, p. 117).

As nascentes, ao longo de milhares de anos, esculpiram bacias de recepção de águas onde o solo era composto por arenitos e argilas, materiais menos resistentes. Onde existiam camadas de solos mais sólidos, de "arenito ou rochas limoníticas", formaram-se os "esporões laterais", que são "[...] pequenos espigões secundários, de topo plano ou ondulado, com rebordos e encostas abruptas". (AB'SÁBER, 2007, p. 117). 
O relevo descrito pelo autor pode ser melhor compreendido através da figura 1. A ilustração contém um mapa topográfico da região da Lapa, situada dentro do centro expandido. $\bigcirc$ recorte escolhido é uma aproximação da área descrita por Ab'Sáber (2017) e abrange a planície fluvial do rio Tietê e uma porção do espigão central. No mapa topográfico, é possível localizar onde os 'esporões laterais' ocorrem com maior frequência. Com base na identificação e caracterização desse relevo, é possível delimitar uma área que, a partir de uma análise mais detalhada, pode fornecer evidências da existência de córregos ocultos, iá que segundo a passagem citada anteriormente, são nesses esporões laterais que se encontram as nascentes da maioria dos córregos da região.

Alguns casos de córregos ocultos, como os córregos Água Branca, Sapateiro, Aclimação, entre outros, já foram explorados por outros pesquisadores, como Vladimir Bartalini. Porém, as pesquisas ainda não cobriram o subdistrito da Lapa. Como verificado anteriormente nos mapas, a região possui as bacias receptoras e os espigões secundários mencionados por Ab'Saber (2007). Além disso, é uma área de urbanização consolidada, que oferece um bom desafio na missão de desvelamento dos cursos d'água, pois exige o exame de várias camadas de urbanização. A figura 2 exibe o subdistrito da Lapa em São Paulo, área escolhida para esta investigação em busca dos córregos ocultos.

Antes de visitar a área delimitada, é possível ampliar ainda mais a escala dos mapas em busca dos córregos ocultos da região. Uma breve pesquisa cartográfica, identificando as principais vias do subdistrito, pode ser útil para identificar algum curso d'água escondido, pois, como é de conhecimento, muitas avenidas de São Paulo apossaram-se das áreas que pertenciam aos córregos. Alguns mapas são particularmente úteis nessa missão, registrando ao longo de décadas a evolução da ocupação do território paulistano. Os mapas mais representativos utilizados nesta investigação foram: mappa topographico do município de São Paulo (1930), realizado pela empresa Sara Brasil; mapa do Município de São Paulo, realizado a partir do levantamento aerofotogramétrico da empresa Viação Aérea São Paulo (VASP) Brasil (1954); levantamento aerofotogramétrico disponibilizado online pela empresa Multispectral (1958); mapa do munícipio de São Paulo, realizado pela Secretaria Municipal de Desenvolvimento Urbano da Prefeitura (SMDU) do município de São Paulo (2004); levantamento fotogramétrico disponibilizado online pelo Google Maps (2012). Próximo à avenida Ricardo Medina Filho, atualmente uma das mais movimentadas da região, encontra-se registrada a presença de alguns córregos que não estão claramente evidenciados nos mapas mais recentes. Entre eles, observa-se um pequeno braço do córrego Tiburtino, localizado no bairro Vila Ipojuca, vizinhança pertencente ao subdistrito da Lapa.

Nas figuras 3, 4 e 5, retiradas das bases mencionadas, é possível observar a presença desse curso d'água que corre para o córrego Tiburtino, mas que atualmente flui escondido pelas calmas ruas no interior do bairro. Assim, a investigação pôde ser 
direcionada a um local específico, onde provavelmente seria possível a identificação de elementos que evidenciam a presença de um curso d'água oculto. Como se verificou posteriormente em pesquisa de campo, a ocultação desse afluente de fato deixou marcas na paisagem, evidenciando sua presença para os olhares mais apurados. Porém, antes da verificação desses signos in loco, é necessário compreender como se formaram, isto é, como se deu o processo que levou à ocultação desse córrego.
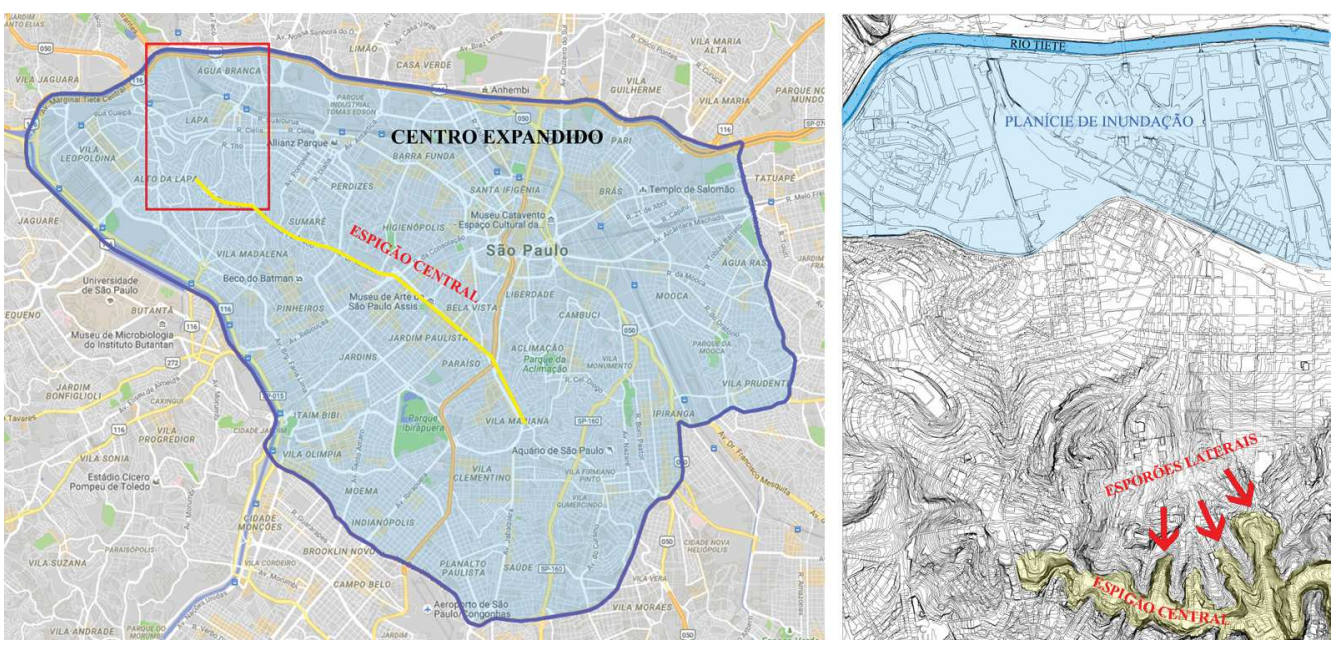

Figura 1 Mapa indicando o minianel viário que delimita a área do centro expandido e um recorte ampliado que exibe as curvas de nível da região da Lapa.

Fonte: Elaborado por Murillo Aggio Piazzi, 2014, com base em levantamento topográfico oferecido pela Prefeitura Municipal de São Paulo, 2005/2006, e base retirada de levantamento fornecido pelo Google Maps, 2012.

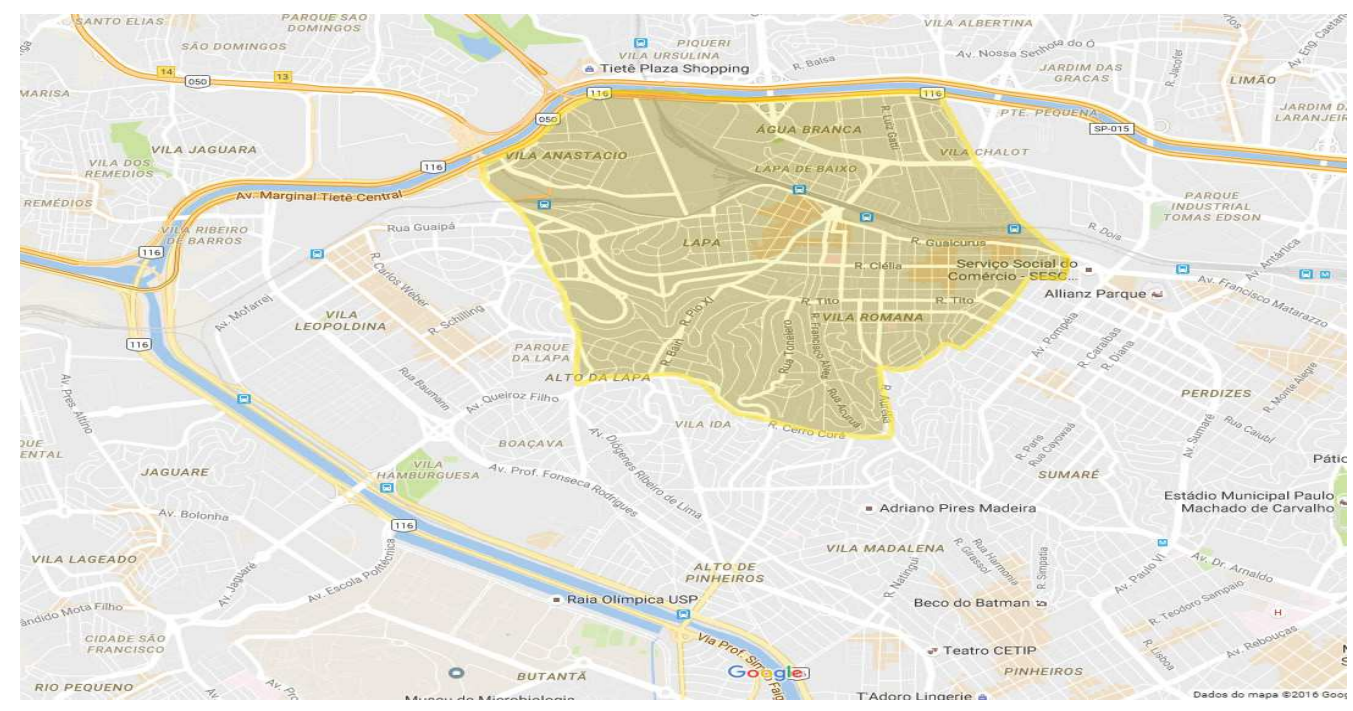

Figura 2 Subdistrito da Lapa, área delimitada para a investigação dos córregos ocultos.

Fonte: Elaborada por Murillo Aggio Piazzi, 2014, com base retirada de levantamento fornecido pelo Google Maps, 2012. 


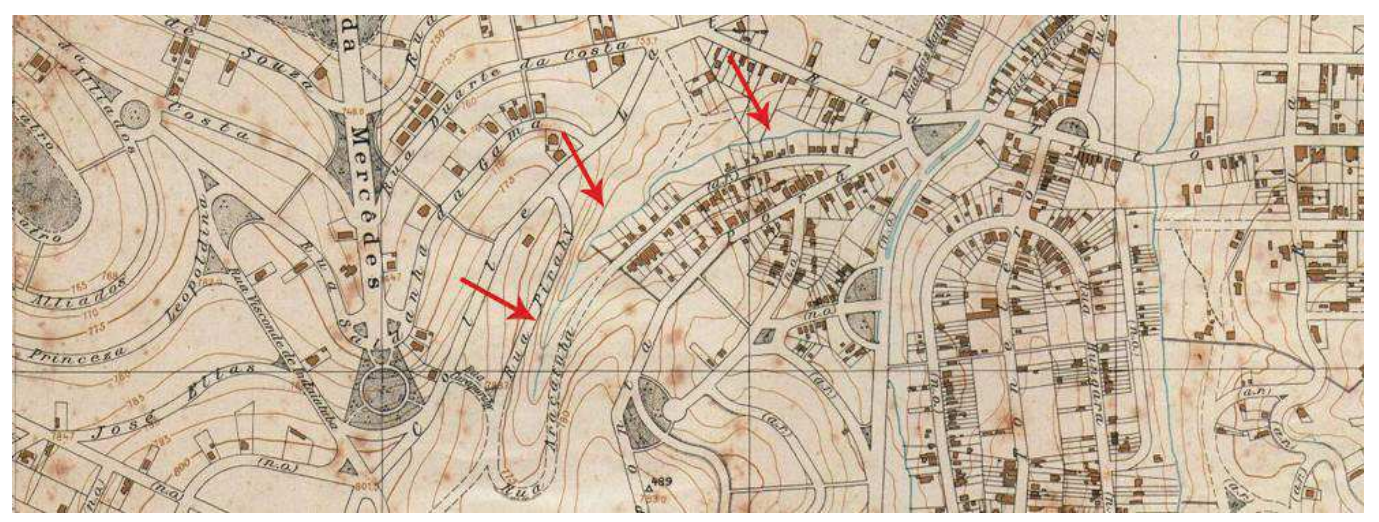

Figura 3 Córrego afluente do córrego Tiburtino em 1930.

Fonte: Mappa topographico do município de São Paulo. Disponível em: <http://geosampa.prefeitura.sp.gov.br/

PaginasPublicas/_SBC.aspx>. Acesso em: 25 ago. 2017.

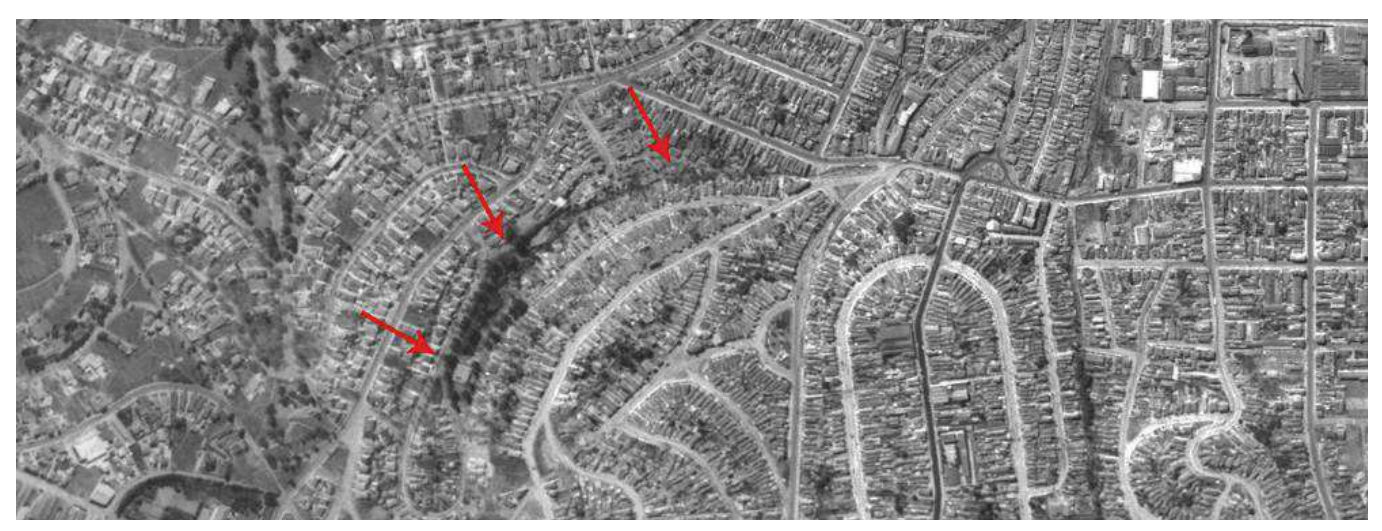

Figura 4 Córrego afluente do córrego Tiburtino em 1958.

Fonte: Fotos aerofotogramétricas do município de São Paulo - Geosampa. Disponível em: <http://www.geoportal. com.br/memoriapaulista/>. Acesso em: 25 ago. 2017.

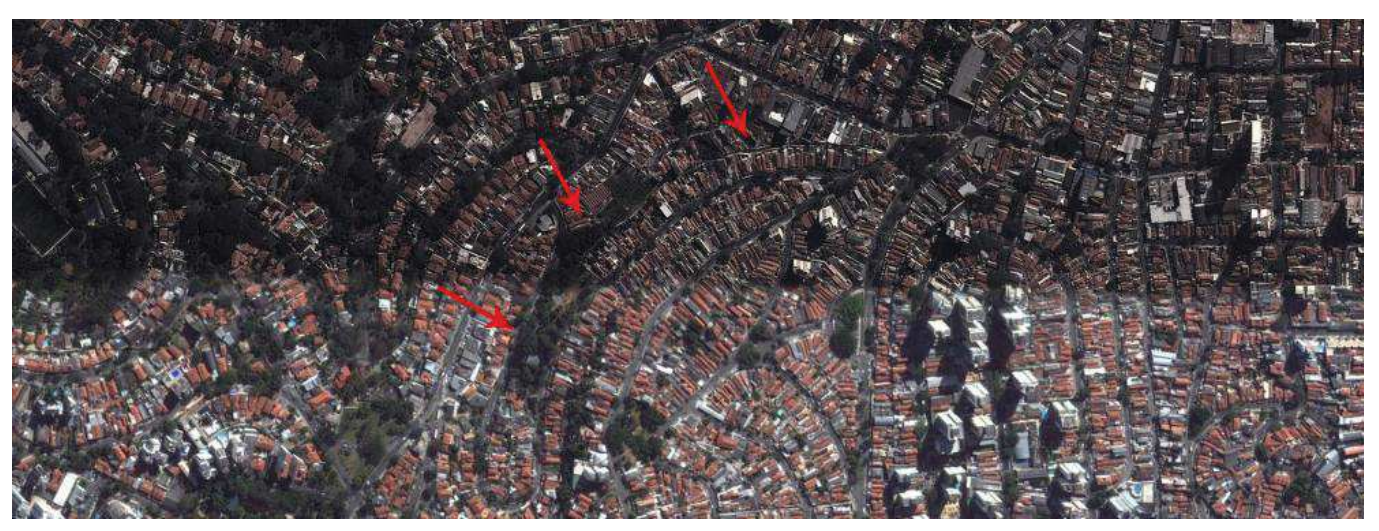

Figura 5 Córrego afluente do córrego Tiburtino em 2012.

Fonte: Google Maps, 2012. Disponível em: <https://www.google.com/maps/@-23.5298352,-

46.7067546,697m/data=!3m1! e3 >. Acesso em: 25 ago. 2017. 


\section{O ENTERRO DE UM CÓRREGO, UMA TRISTE HISTÓRIA}

Por vezes, em busca de um sinônimo para a palavra córrego, utiliza-se o epíteto 'corpo d'água'. Se um córrego também pode ser entendido como um corpo, o corpo do córrego descoberto nas pesquisas cartográficas está inteiramente enterrado na Vila Ipojuca. Seu caixão são as antigas galerias que conduzem suas águas por debaixo das ruas, praças e vielas do bairro. A história desse enterro se desenrolou na primeira metade do século XX, período de expansão da área urbana de São Paulo. É nesse período que a área de relevo irregular, ocupada pelo córrego estudado, começa a ser urbanizada (PRADO JR., 1998).

A ocupação da região da Lapa começou a mostrar-se expressiva em meados da década de 1920. Até então, o bairro era conhecido por suas várias chácaras, que passaram por diferentes proprietários desde a época colonial (SANTOS, 1980). O aumento do número de loteamentos nesse distrito, sobretudo aqueles destinados às classes populares, está intimamente ligado à valorização dos terrenos em São Paulo. Com o aumento dos preços dos terrenos melhor localizados, isto é, próximos à infraestrutura e ao transporte, os loteadores se viram forçados a procurar terrenos baratos, que geralmente se encontravam em áreas acidentadas, sem infraestrutura e cada vez mais distantes do centro da cidade (KAWAl, 2001).

A situação topográfica dos terrenos mais baratos exigia grande habilidade por parte dos loteadores. Em geral, as glebas ainda livres possuíam áreas com grande declividade. Essa característica foi bem aproveitada pelos bairros-jardins produzidos pela Companhia City, que soube utilizar essa topografia singular para construir loteamentos de alto padrão a baixos custos nessas áreas ainda desocupadas. A estratégia de projeto utilizada pelos projetistas da companhia resultou no traçado de ruas sinuosas, acompanhando as curvas de nível das colinas a fim de obter rampas de inclinação suave (KAWAl, 2001).

O sucesso desses loteamentos fez com que, em pouco tempo, seus traços gerais fossem replicados para loteamentos destinados às classes populares. Em poucas palavras, esses traços podem ser resumidos como: a apropriação orgânica e racional do espaço natural; a concepção do espaço público das ruas e praças como o lugar da vida social; a presença da natureza na cidade, valorizando sua dimensão lúdica e estética (KAWAl, 2001).

O córrego afluente do Tiburtino, identificado anteriormente nos mapas, fica na fronteira de dois loteamentos distintos, ambos classificáveis como bairro-jardim - um de alto padrão e outro de padrão médio. $O$ primeiro, conhecido como Alto da Lapa, foi feito pela Cia. City, com projeto do famoso arquiteto e urbanista Barry Parker, lançado em 1927. Já o segundo, conhecido como Vila Ipojuca, data do início da década de 1920, e foi ocupado principalmente por imigrantes, sendo que o autor do projeto não está identificado (PONCIANO, 2001, p. 228). Tudo o que se sabe é que o responsável pelo empreendimento foi Luís Pereira de Queirós, que contratou um topógrafo para 
realizar o desenho do arruamento, o que era permitido na época. Interessantemente, esse topógrafo provinha de Pernambuco, e em sua terra natal havia um rio chamado Ipojuca, que cedeu nome ao loteamento. Esse nome tem raízes no tupi, yapó-yuca, que significa riacho ou brejo (PONCIANO, 2001). É provável que tal conexão de nomes seja uma menção à presença de um córrego na gleba loteada.

Córregos, valos e elementos topográficos marcantes eram, e ainda são, utilizados como demarcadores de propriedades. As fichas do Arquivo Aguirra fornecem provas de que na Lapa as glebas também eram demarcadas dessa maneira. Neste excerto, registra-se a demarcação das posses de dois proprietários da região para a realização de uma negociação de compra e venda: "[...] um sítio que parte com terras dele vendido, de outro lado com córrego Pereira e segue pelo ribeirão Mandeí [atual Tiburtino, canalizado] até o Rio Tietê e junto a estrada e caminho de baixo que vai para o pasto do Coronel Anastácio". (ARQUIVO Aguirra, 1980).

Os córregos da região aparecem várias vezes nas notas do Diário Oficial do Estado de São Paulo, sendo utilizados com a mesma finalidade. Neste excerto, os corpos d'água servem como divisas que delimitam a área das subdelegacias da capital:

Décima Subdelegacia

(Vila Ipojuca)

Começam na rua Marcelina, junto ao córrego da Água Preta, e seguem pela referida rua (exclusive) até encontrar o córrego do Tiburtino ou do Mandy. Continuam por este córrego (exclusive), até alcançar suas cabeceiras e destas, em linha reta (exclusive), até encontrar a estrada do Araçá, ao Alto da Lapa, seguindo por esta estrada (exclusive), até a estrada que da Avenida Municipal vai ter ao Reservatório do Araçá (tudo exclusive), seguindo deste ponto, em linha reta até encontrar o córrego Água Preta e por este (exclusive), até o ponto onde tiveram começo. (DIÁRIO Oficial do Estado de São Paulo, 1934, p. 5)

Ao serem caracterizados como divisa de propriedades, gera-se um dilema acerca da responsabilidade de conservação dos córregos. Sem deveres bem definidos, em um jogo de empurrar o problema para o vizinho, os corpos d'água foram geralmente tratados com descaso. A falta de infraestrutura nos loteamentos populares, sobretudo a falta de saneamento, fez com que se tornassem poluídos - e suas várzeas, degradadas, criando assim um problema às áreas adjacentes. Em discurso proferido em 1948, na Câmara dos Vereadores, o vereador Jânio Quadros já deixava claro qual era a situação dos córregos da Lapa:

O Sr. Cunha Mattos - V. Excla. permite um aparte? Na Lapa existe mais além um córrego sobre cujo nome há um equívoco: não é Tiberino, é Tiburtino.

O Sr. Jânio Quadros - Excelência, morador algum pode dar-me o nome exato desse córrego, mas tiveram a gentileza de fornecer-me fotografias do mesmo. 
O Sr. José de Moura - Darei o nome, se V. Excita. me permitir: é o córrego Pestilento.

O Sr. Jânio Quadros - É a denominação exata: é um córrego doentio.

O Sr. Cunha Mattos - Aliás, na Lapa, há mais dois córregos nas mesmas condições, correndo entre áreas edificadas nesta mesma situação anti-higiênica.

O Sr. José de Moura - Igualmente pestilentos.

O Sr. Jânio Quadros - Córregos propriamente, não encontrei mais. Encontrei apenas as casas das adjacências deste Tiburtino...

O Sr. Sebastião Casetti - É Tiberino...

O Sr. Jânio Quadros - Tibutino [sic], ou Tiberino, de qualquer forma ele está fotografado. Encontrei apenas as casas das adjacências deste córrego, com amuradas... com amuradas como deveriam ter as casas lacustres, para defesa contra enchentes, e estas enchentes verificam-se rigorosamente a cada ano (DIÁRIO Oficial do Estado de São Paulo, 1948, p. 37).

No entanto, a existência de um corpo d'água poluído nos arredores das residências vinha se tornando um problema sério e intolerável para os moradores da cidade, pois:

[...] a higiene se aliou intimamente aos ideais de construção de uma nação vigorosa, salubre e em franco progresso. A justificativa da salubridade se tornou uma constante em discursos favoráveis ao desenvolvimento comercial e moral da cidade, mas também uma ótima justificativa para ações especulativas de compra e vendas de terrenos (SANT'ANNA, 2007, p. 33).

A higiene ocupou lugar de destaque nas discussões públicas nas primeiras décadas do século $X X$, pois estava ligada diretamente à prevenção de epidemias. No início do século, o medo do surto de doenças contagiosas era crescente. Quadros alarmantes eram registrados em cidades próximas, como Campinas, na qual se estima que o número de mortos por febre amarela tenha chegado a 1.200 em 1899 (SANTOS FILHO, 1996, p. 137-43).

O temor de epidemias se intensificava, ao passo que a ciência avançava e começava a desvendar os mistérios das patologias. Os avanços pasteurianos na área da microbiologia começaram a ser difundidos no Brasil na década de 1890, principalmente pelo trabalho pioneiro de Oswaldo Cruz. Após a divulgação dos avanços científicos, a noção de que os micróbios estavam em todos os lugares se difundiu rapidamente entre a população (SANT'ANNA, 2007). Doenças eram transmitidas por micróbios que poderiam estar presentes nas águas. Contudo, a população ainda não havia entendido muito claramente o que eram esses seres. Por vezes, os micróbios eram combinados com os antigos miasmas como fonte das doenças. Logo, "[...] miasmas e micróbios começaram a ser, indistintamente e cada vez mais intensamente, um problema típico das águas impuras". (SANT'ANNA, 2007, p. 225-226). Águas de chafarizes, tanques e córregos passam a ser suspeitas. 
Em 1904, o secretário de águas de São Paulo já alertava sobre o perigo de lançar os esgotos sem tratamento no rio Tietê, o que, segundo o conhecimento da época, gerava miasmas de onde provinham as doenças. Para ele "[...] a única solução será o tratamento das matérias dos esgotos, para purificá-los antes de lançar no rio" (CORREIO Paulistano, 1903, p. 3). Se mesmo no início do século XX já se sabia da importância da coleta e tratamento dos esgotos, no período em que se lançaram os loteamentos na Lapa, na década de 1920, ainda não havia rede de coleta e tratamento que cumprisse plenamente esse papel na cidade.

O problema da polvição dos corpos d'água passou a ser combatido ainda no século XIX, a partir da criação da Companhia Cantareira de Águas e Esgotos, em 1877. No entanto, após sua criação a companhia restringiu a construção da infraestrutura de esgoto nas áreas mais nobres e centrais da cidade. Enquanto isso, por décadas, os bairros populares e os distritos afastados continuaram a tratar seu lixo da mesma forma que se fazia tradicionalmente. A maior parte dos resíduos gerados nas edificações desses bairros era armazenada em fossas sépticas ou despejadas nos rios, ruas e terrenos baldios (JORGE, 2006). Assim, os dejetos dependiam do volume dos rios para serem dissolvidos e do ritmo da natureza para serem decompostos, que não dava conta da crescente quantidade de detritos gerados pela população.

Assim, de fato, os córregos traziam problemas sanitários para aqueles que residiam próximo das suas margens. A ação mais frequentemente tomada pelo poder público nesses casos foi a simples canalização dos corpos d'água, dando continuidade a uma tradição sanitarista que se estabelecia desde o início do século XX. O córrego localizado na Vila Ipojuca não fugiu dessa tendência. Diversas vezes são os próprios moradores do bairro que exigem a canalização:

\section{Requerimento N. 1650-56}

Requeiro à Mesa, oficie ao Senhor Prefeito Municipal, solicitando as informações seguintes:

Sabe S. Exa. que existe um riacho perigoso chamado Córrego Tiburtino no bairro de Vila Ipojuca, entre a rua Tito e a rua Camilo, que vem corroendo os muros das residências, chegando mesmo a abalar os alicerces de algumas delas?

Sabe S. Exa. que o ex-prefeito Sr. Lino de Matos, teve oportunidade de verificar no local a grave irregularidade, constatando a necessidade urgente da construção de galerias, que, apesar de iniciadas, não foram, inexplicavelmente, concluídas?

Quais os planos existentes para o local e quando espera o executivo terminar as obras iniciadas? - Sala das Sessões, 17 de setembro de 1956. - Jacob Zveibvil "Oficie-se" (DIÁRIO Oficial do Estado de São Paulo, 1956, p. 67).

Não se obteve registros sobre o ano exato de canalização desse córrego em particular. Porém, a canalização do córrego Tiburtino foi aprovada em 1947 (DIÁRIO Oficial do Estado de São Paulo, 1951, p. 41). Com base em entrevistas com moradores da 
região e posterior comprovação nas bases cartográficas, sua porção inicial, onde está a nascente, já se encontrava em galerias em meados da década de 1950, assim como o seu encontro com o córrego Tiburtino. Sua porção central, onde hoje se encontra a praça Dr. Octávio Perez Velasco, foi canalizada na década seguinte.

\section{DESVELANDO O CÓRREGO}

Embora o córrego da Vila Ipojuca tenha sido canalizado e soterrado pela cidade em desenvolvimento, ainda hoje suas águas correm naquele bairro. Apesar de não ser possível observá-las fluindo a céu aberto, ainda se pode notar os signos deixados por esse curso d'água na paisagem. Assim, em uma visita ao local identificado anteriormente nos mapas, é possível observar os elementos que denunciam sutilmente a presença do córrego oculto. A exploração do curso d'água foi dividida em dois trechos, exibidos na figura 6. Ambos se iniciam em uma praça, onde se localiza um marco paisagístico que evidencia a presença do córrego. A escolha desse marco como ponto inicial dos percursos tem como finalidade facilitar a exploração por aqueles que possuam algum interesse em reproduzir o trajeto futuramente. $\bigcirc$ primeiro trajeto segue a montante, até a região da nascente; o segundo cobre o restante do curso do córrego até a sua foz no principal corpo d'água da região, o córrego Tiburtino.

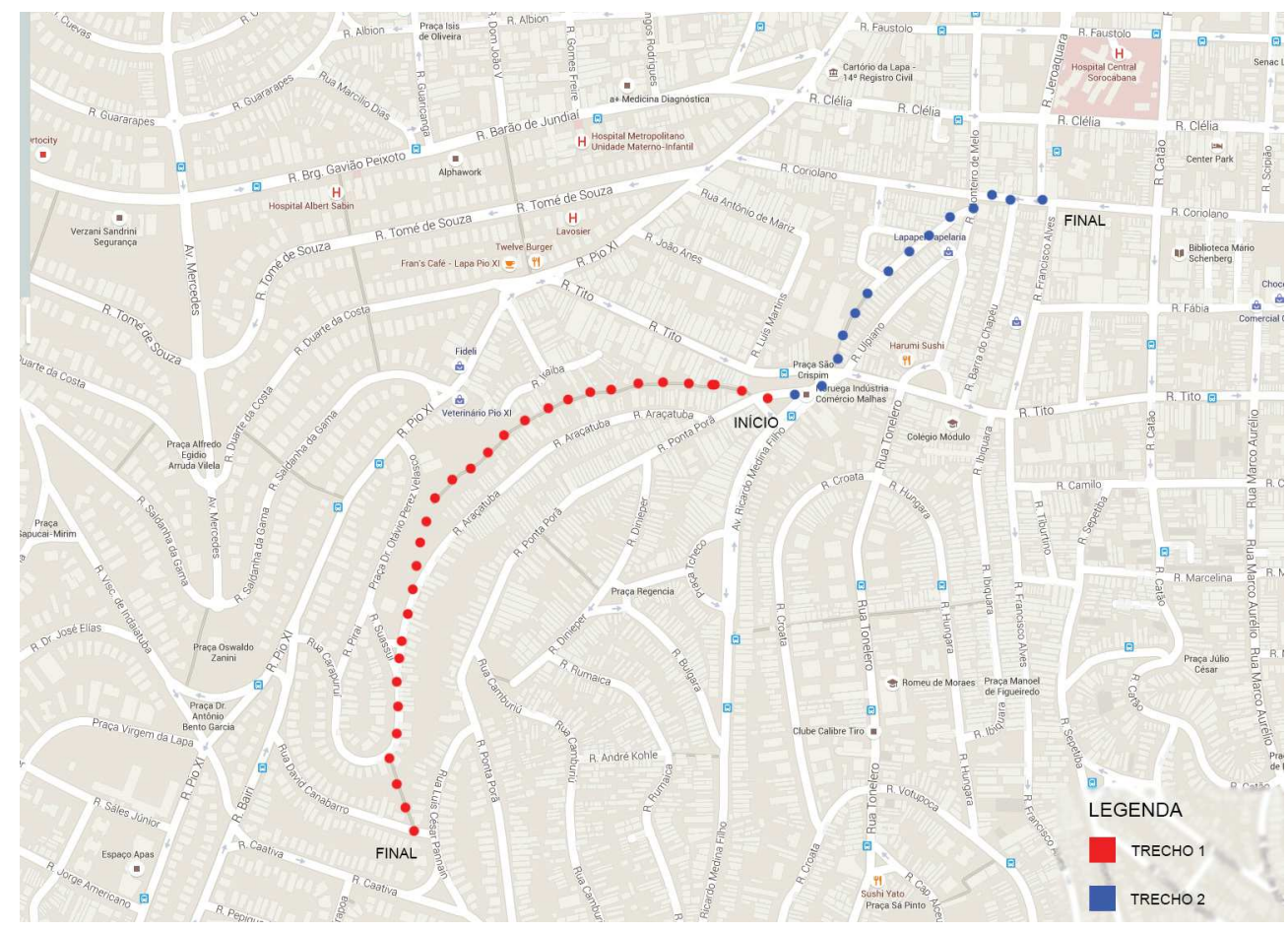

Figura 6 Trajetos percorridos na pesquisa de campo.

Fonte: Elaborada por Murillo Aggio Piazzi, 2014, com base retirada de levantamento fornecido pelo Google Maps 2012. 


\section{O CAMINHO ATÉ A NASCENTE (TRECHO 1)}

A primeira impressão ao chegar na zona de estudo delimitada, na Vila lpojuca, é a de uma geografia que se faz sentir (figuras 7a e 7b). Situados na porção ocidental do espigão central, os bairros têm ruas íngremes e sinuosas.

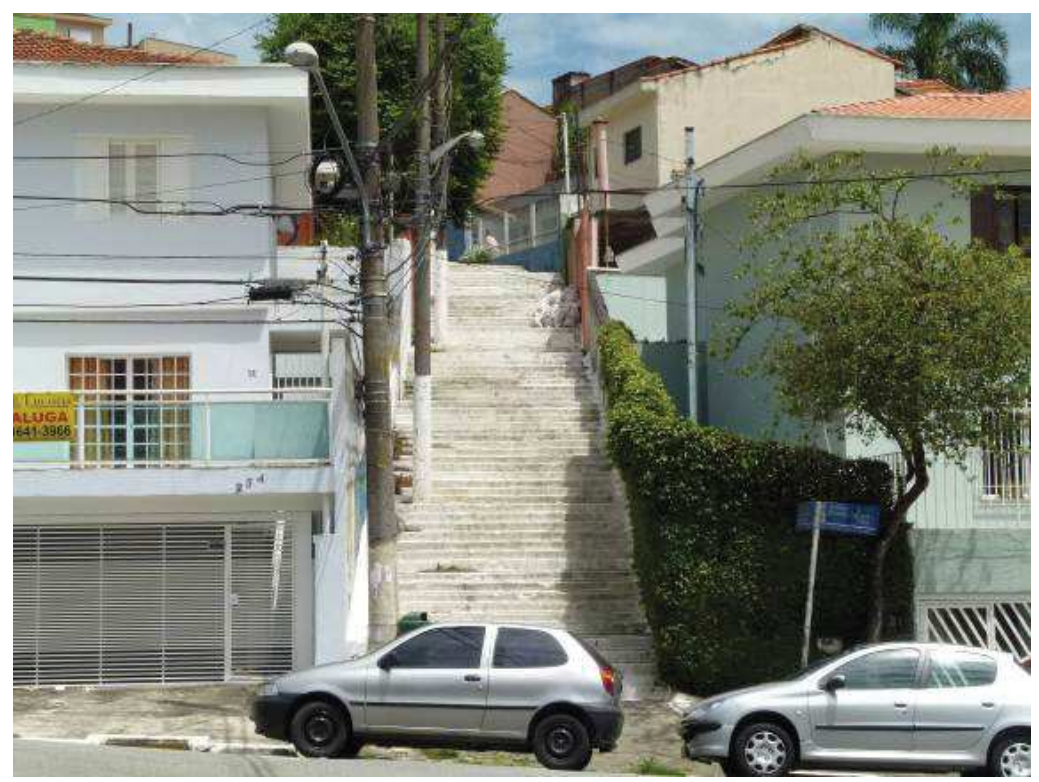

Figura 7a Exemplo da topografia acidentada da Lapa em São Paulo. Foto: Murillo Aggio Piazzi, abr. 2014.

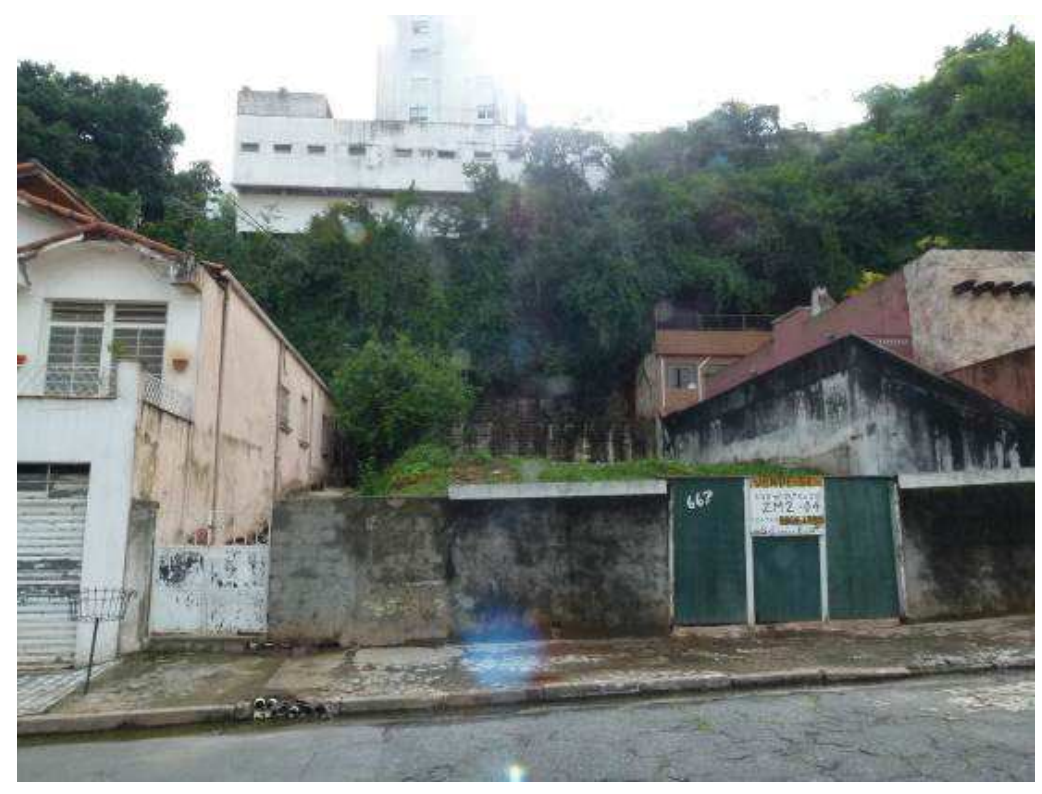

Figura 7b Exemplo da topografia acidentada da Lapa em São Paulo. Foto: Murillo Aggio Piazzi, abr. 2014. 
Na parte mais baixa da rua Ponta Porã, que liga a parte mais alta do bairro (avenida Cerro Corá) à sua porção menos elevada, encontra-se forte evidência de um córrego que foi oculto (figura 8). Esse é o ponto inicial do trajeto que será feito até a nascente do córrego.

Na praça São Crispim, de caráter mais ligado ao trânsito local, encontra-se um beco que corta ao meio o quarteirão delimitado pelas ruas Araçatuba, Tito, Pio XI e Piraí. Adentrando esse beco, formado pelos muros dos fundos das casas do quarteirão, segue-se para uma cota mais elevada. Sua característica mais marcante é a de aparentar ser um local abandonado onde poucos moradores se arriscariam a cortar caminho. Há muito lixo e a vegetação está por ser cortada. Ao longo do trajeto pode-se observar a presença de grades sobre o chão do beco (figura 9), onde é possível visualizar e escutar o córrego fluindo - a primeira evidência concreta da existência de um córrego oculto naquele local.

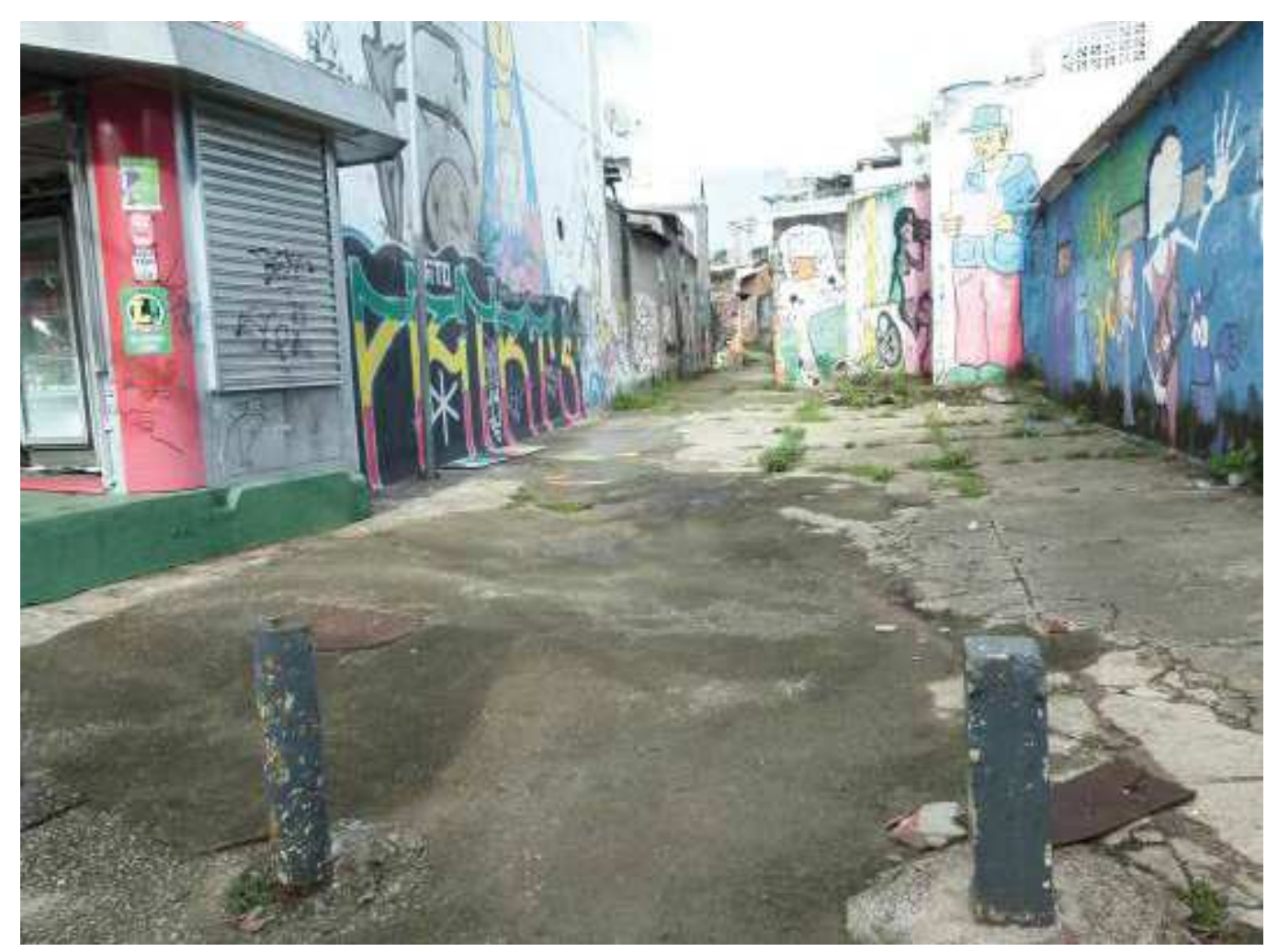

Figura 8 Entrada para o beco que segue o curso do córrego. Foto: Murillo Aggio Piazzi, abr. 2014.

À medida que se alcança cotas mais elevadas, outros elementos, como tampas de bueiros, tubulações e escadarias, se revelam. Do mesmo modo que se inicia, o percurso do beco termina em uma praça (praça Dr. Octávio Perez Velasco) de caráter mais local, situada no interior do bairro residencial. $O$ caminho que conecta essas duas praças 
poderia ser melhor aproveitado, oferecendo um percurso agradável, longe do barulho dos carros. O fluir das águas guiaria os pedestres de uma praça à outra. No entanto, tal possibilidade dá lugar à viela suja, à qual até mesmo as casas dão às costas, onde o córrego malcheiroso segue confinado, correndo por debaixo das grades.

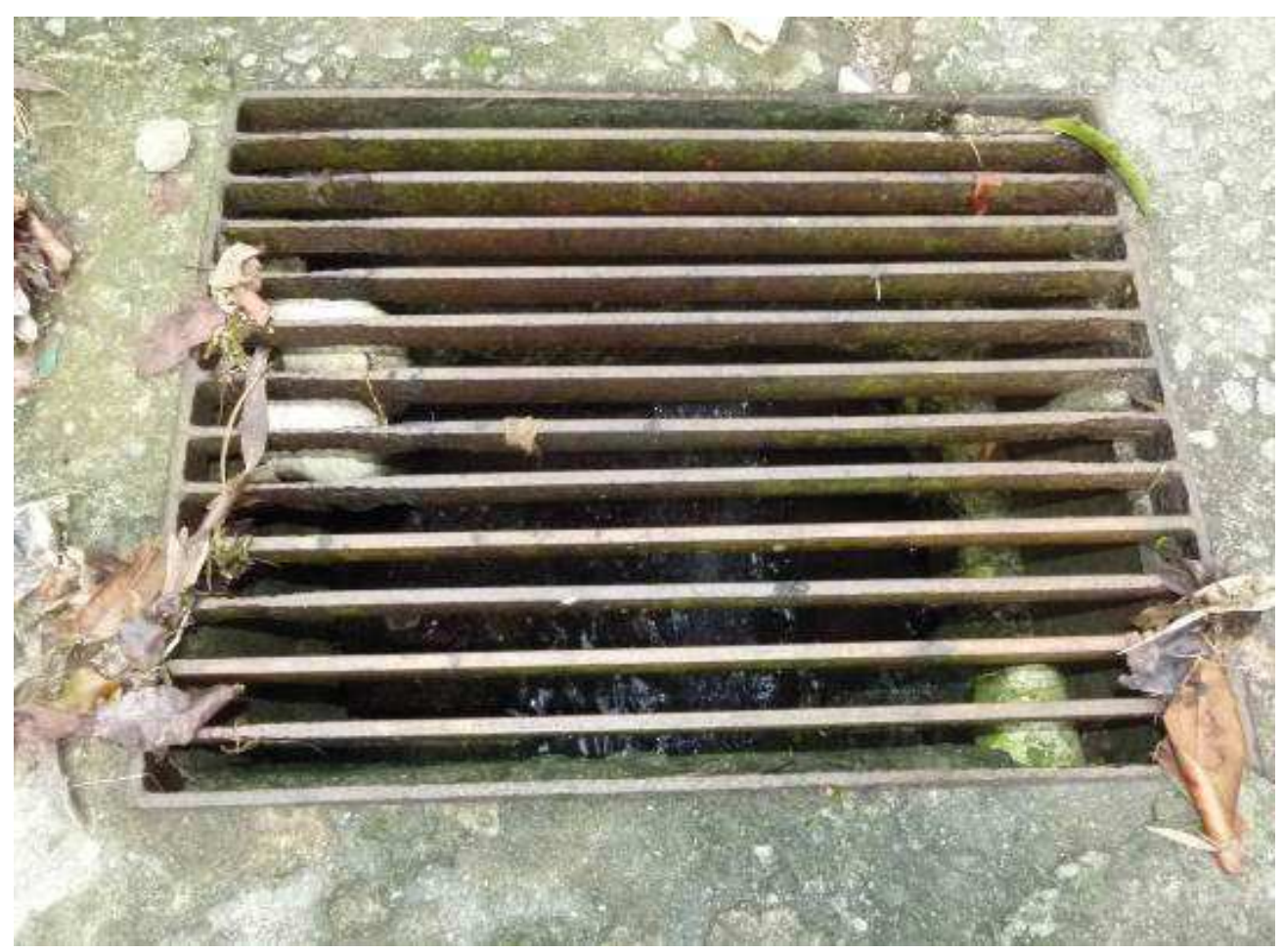

Figura 9 Grade por onde se pode enxergar o córrego fluindo. Foto: Murillo Aggio Piazzi, abr. 2014.

Prosseguindo o percurso, nota-se que o córrego canalizado passa sob a praça Dr. Octávio Perez Velasco. Nela há uma biblioteca municipal onde ocorrem alguns eventos da comunidade do bairro, como o encontro semanal de senhoras costureiras. Esses encontros foram fonte de relatos sobre a memória do córrego ainda viva nos moradores mais antigos da região, como o ato cotidiano de abastecer-se da água daquele córrego.

A dificuldade para encontrar o local exato da sua nascente torna-se maior nesse ponto. Nenhuma característica topográfica marca sua presença no local. Uma pesquisa com moradores antigos do bairro revelou que, um pouco mais acima da praça Dr. Octávio Perez Velasco, iá houve um tanque, onde nos primórdios do loteamento se costumava pegar água pura (figura 10). Tal informação é essencial para confirmar a proximidade que se está da nascente, iá que é comum que bicas e tanques se localizem próximo aos olhos d'água, devido à pureza das águas nas proximidades de nascentes. De fato, um pouco mais acima, há outra viela onde se pode ver mais uma vez o córrego fluindo sob a boca de um bueiro (figura 11). 


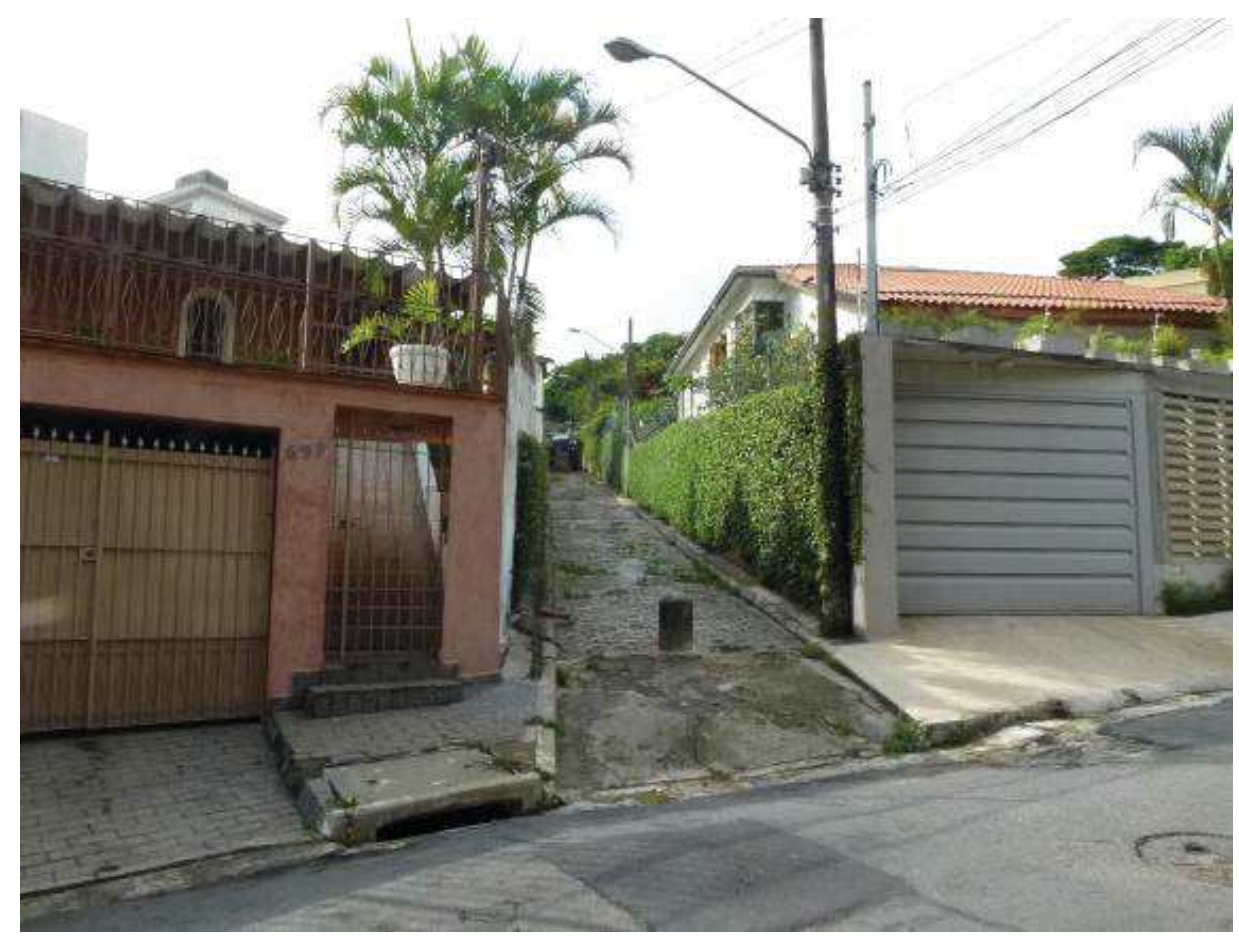

Figura 10 Final da segunda viela encontrada, local onde provavelmente se encontrava o tanque. Foto: Murillo Aggio Piazzi, abr. 2014.

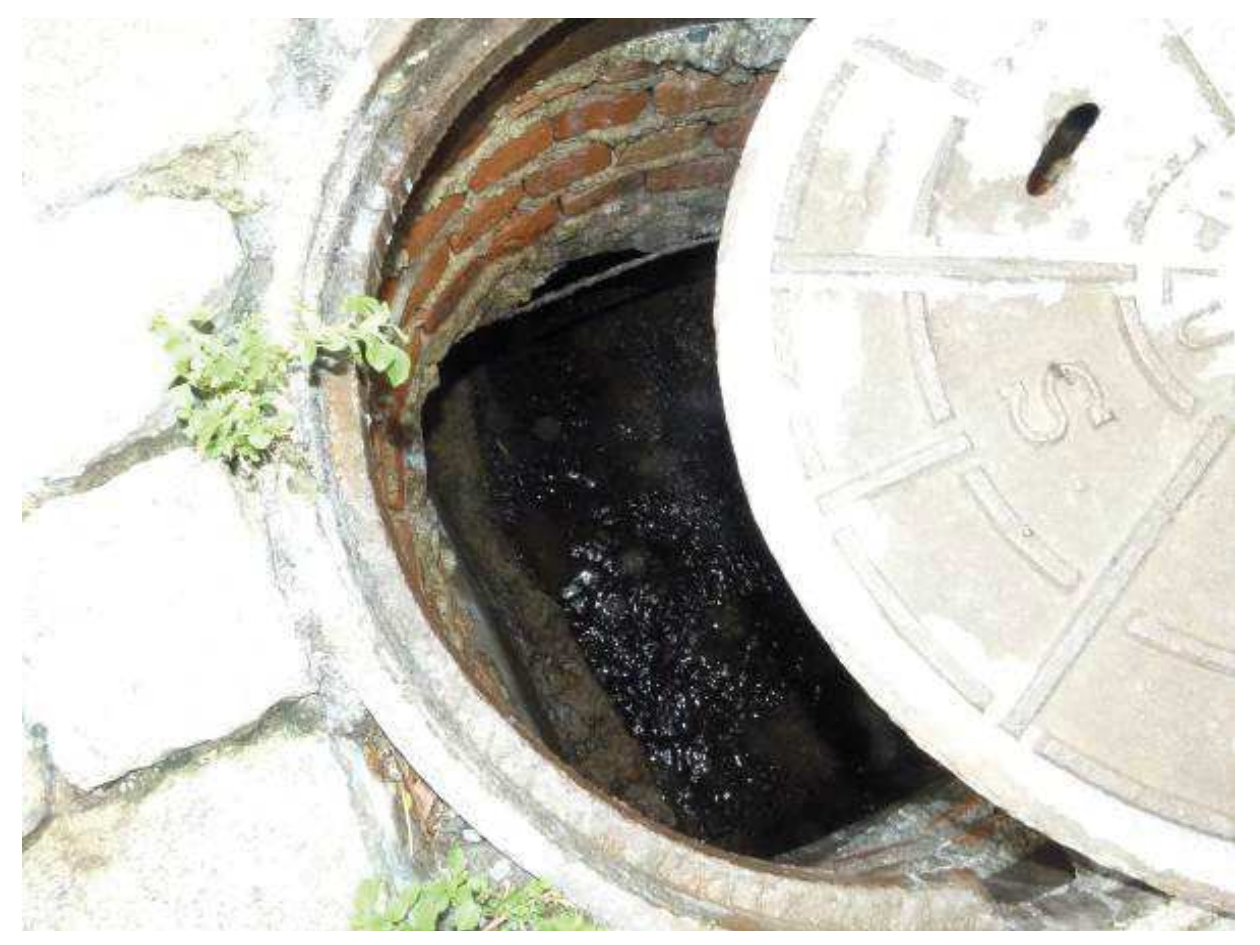

Figura 11 Bueiro por onde pode se ver mais uma vez o córrego. Foto: Murillo Aggio Piazzi, abr. 2014. 
A partir desse ponto, é possível perceber uma série regular de bueiros com a inscrição 'Águas Pluviais' da Prefeitura de São Paulo. Esses bueiros dão acesso a uma antiga galeria por onde passa o córrego. Seguindo tal traçado até o final da canalização, descobre-se, porém, que o final da galeria não coincide com a nascente do córrego estudado - que se encontra em um ponto mais a jusante (figura 12). Uma hipótese para esse fato é que a ocupação do entorno da nascente por edifícios fez com que aquela se deslocasse para um nível inferior. Esse fenômeno ocorre pela compactação do solo gerada pelas edificações próximas ao afloramento d'água.

Nada indica o local da nascente para as pessoas que passam por ali. Apesar de possuir uma característica singular, essa rua aparenta ser apenas mais uma como tantas outras em São Paulo. Ruas onde se observam mais carros em trânsito do que pedestres, e mais asfalto e concreto do que áreas verdes com jardins.

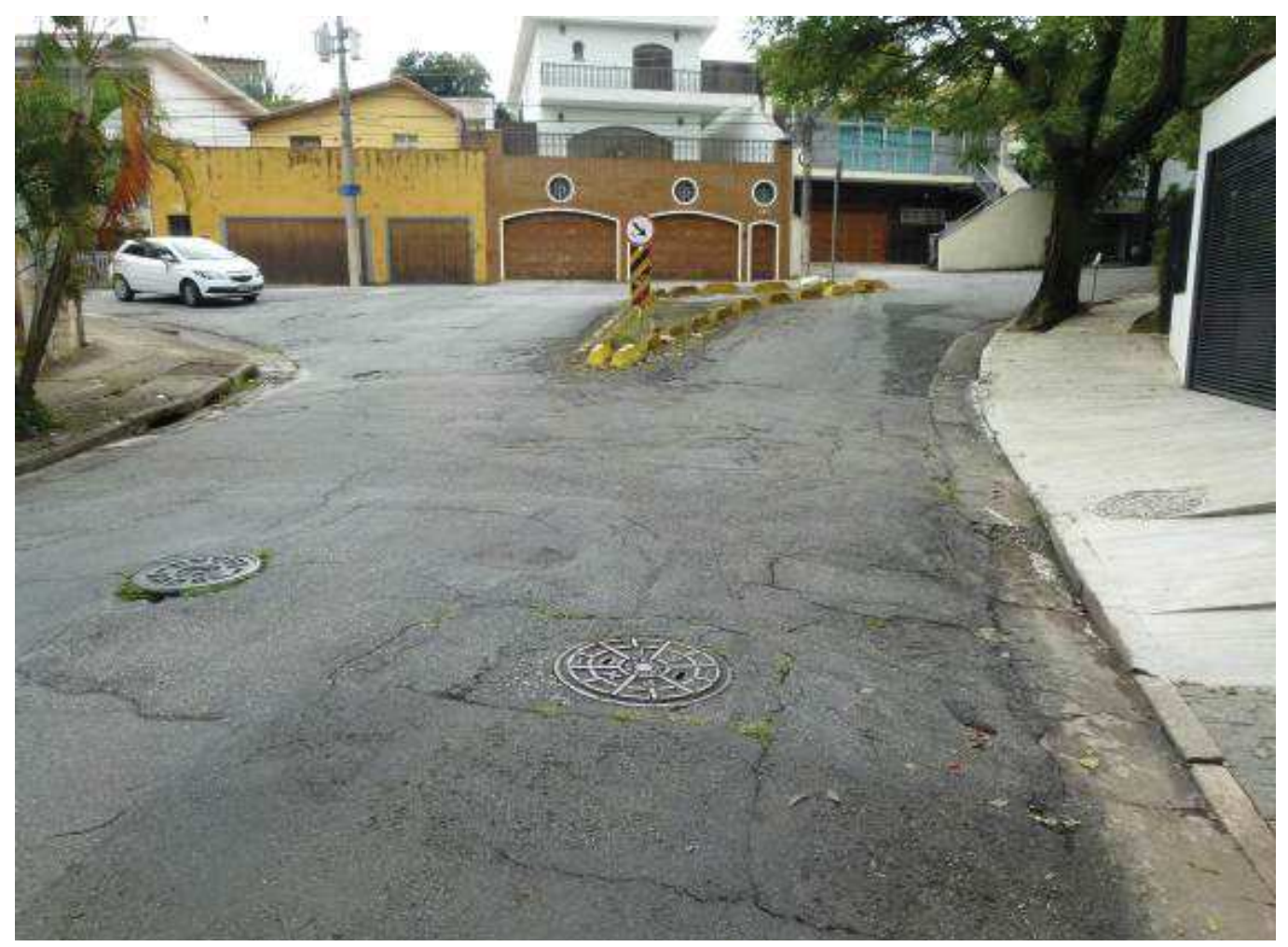

Figura 12 Local da nascente do córrego. Foto: Murillo Aggio Piazzi, abr. 2014.

\section{O PERCURSO ATÉ A FOZ (TRECHO 2)}

Descoberta a nascente, faz-se agora o caminho inverso, para revelar onde o córrego deságua. Próximo à praça São Crispim (ponto de partida por onde se entra no primeiro beco), descobre-se uma continuação da galeria sob uma viela (figura 13). 


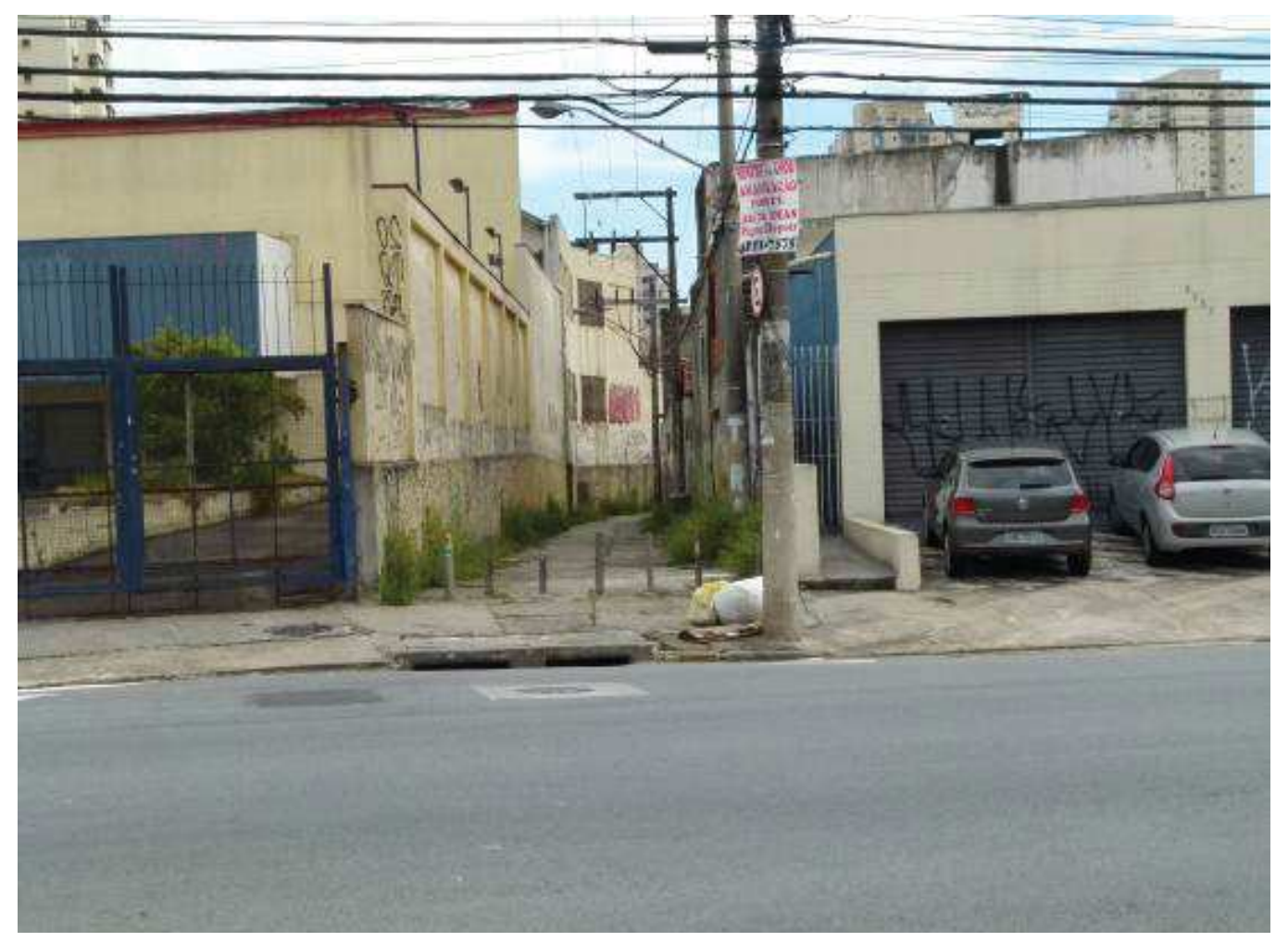

Figura 13 Continuação da viela após a praça São Crispim. Foto: Murillo Aggio Piazzi, abr. 2014.

Esse beco, que se iguala aos demais pelo estado de abandono, conduz à rua Bartolomeu Belli, construída sobre o córrego canalizado. É interessante notar como as edificações que se encontram nessa rua estão particularmente degradadas em relação às do entorno. Tradicionalmente, as várzeas foram locais degradados no território paulistano, sujeitas a frequentes inundações, focos de doenças e abrigo da população que não possuía renda suficiente para instalar-se em locais de maior prestígio. Nesse caso, pelo fato de o córrego estar totalmente oculto, é quase impossível identificar uma área de várzea. No entanto, a tendência parece não ter sido abandonada: aquelas casas são, de fato, as mais degradadas da região.

Um pouco mais adiante pode-se localizar a intersecção dessa galeria com outra, maior. Trata-se do encontro do 'córrego afluente' da Vila Ipojuca com o maior córrego da região (também totalmente oculto) - o córrego Tiburtino. Atualmente, a foz do córrego dá lugar a um movimentado cruzamento (figura 14). Ao invés das águas, são os carros que correm nos leitos desses corpos d'água.

O córrego Tiburtino, por sua vez, é facilmente identificável, pois quase a totalidade de sua extensão é acompanhada por uma única via, a rua Francisco Alves. Sua foz está isolada por dez pistas de trânsito expresso no rio Tietê. Não fosse o fato de seu nome estar discretamente escrito na parede da saída da galeria (figura 15), terminaria tão 
anônimo quanto começou ao aflorar em uma de suas nascentes - sem nenhum impacto expressivo na paisagem que faça alguém notar que há um córrego sob os seus pés.

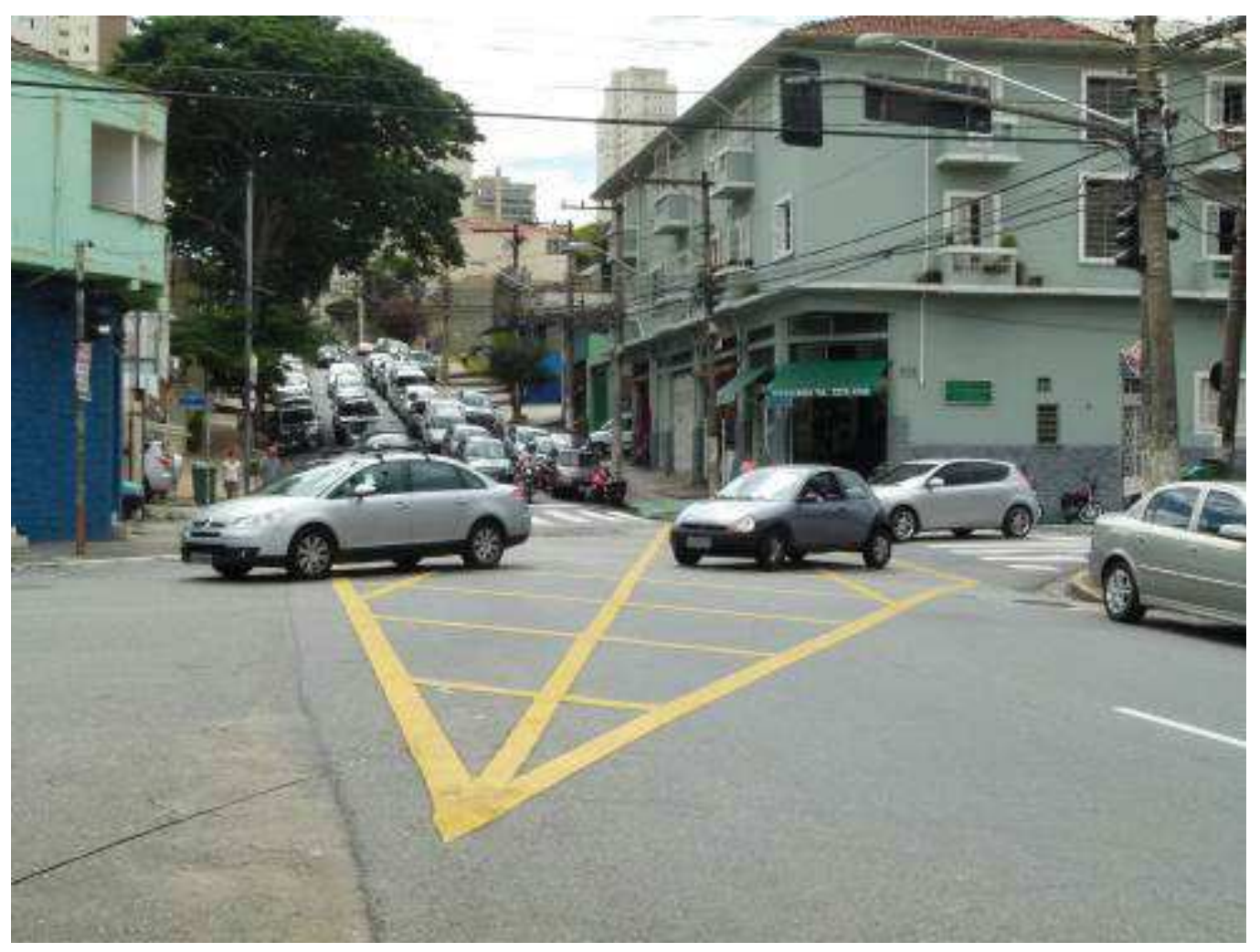

Figura 14 Local de encontro dos córregos. Foto: Murillo Aggio Piazzi, abr. 2014.

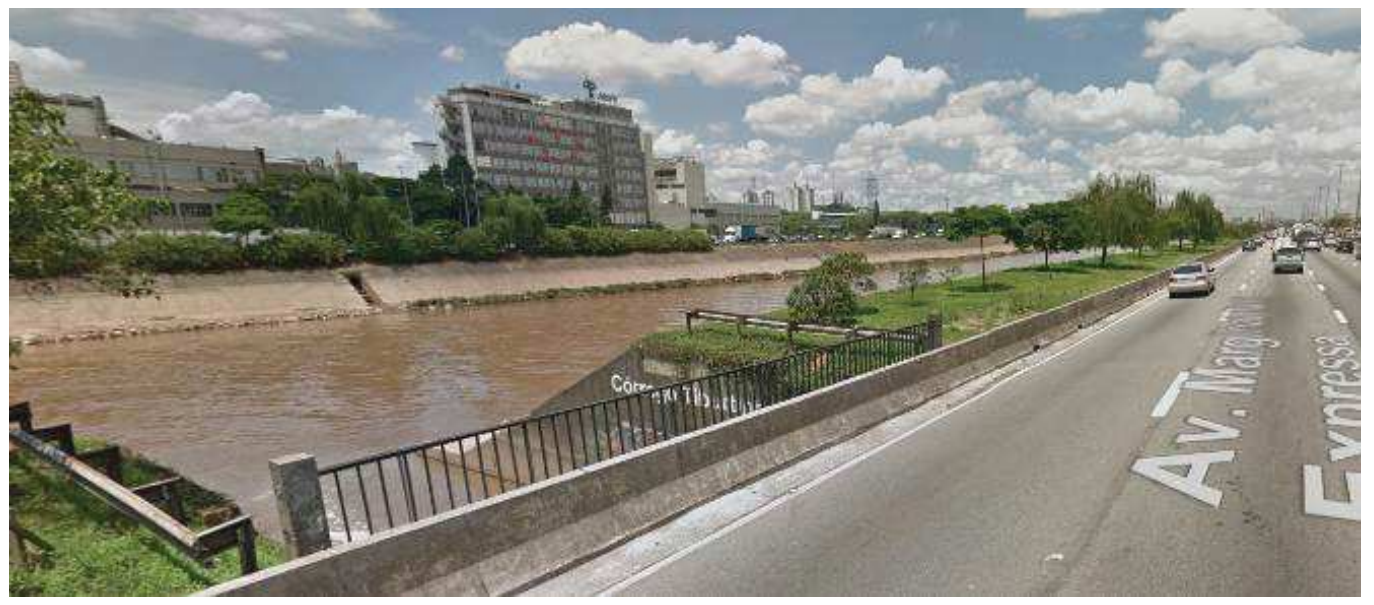

Figura 15 Foz do córrego Tiburtino.

Fonte: Google Street View. Disponível em: <https://www.google.com.br/maps/@-23.5088185,-

$46.7011788,3 \mathrm{a}, 75 \mathrm{y}, 55.11 \mathrm{~h}, 79.49 \mathrm{t} / \mathrm{data}=! 3 \mathrm{~m} 7 ! 1 \mathrm{e} 1 ! 3 \mathrm{~m} 5 ! 1$ sDykbtqqYtdzK3Yq9hrwi-g!2e0!5s20141101T000000 !7i13312!8i6656?hl=pt-BR\&authuser=0 > . Acesso em: 28 ago. 2017. 
Ao final da pesquisa de campo, descobre-se que não há apenas um córrego oculto na região, mas sim uma bacia hidrográfica inteira, totalmente encoberta sob os diversos níveis de urbanização que se acumularam ao longo dos anos. Os córregos identificados na bacia do Tiburtino estão representados na figura 16, assim como a localização dos elementos exibidos nas fotos tiradas durante os percursos realizados.
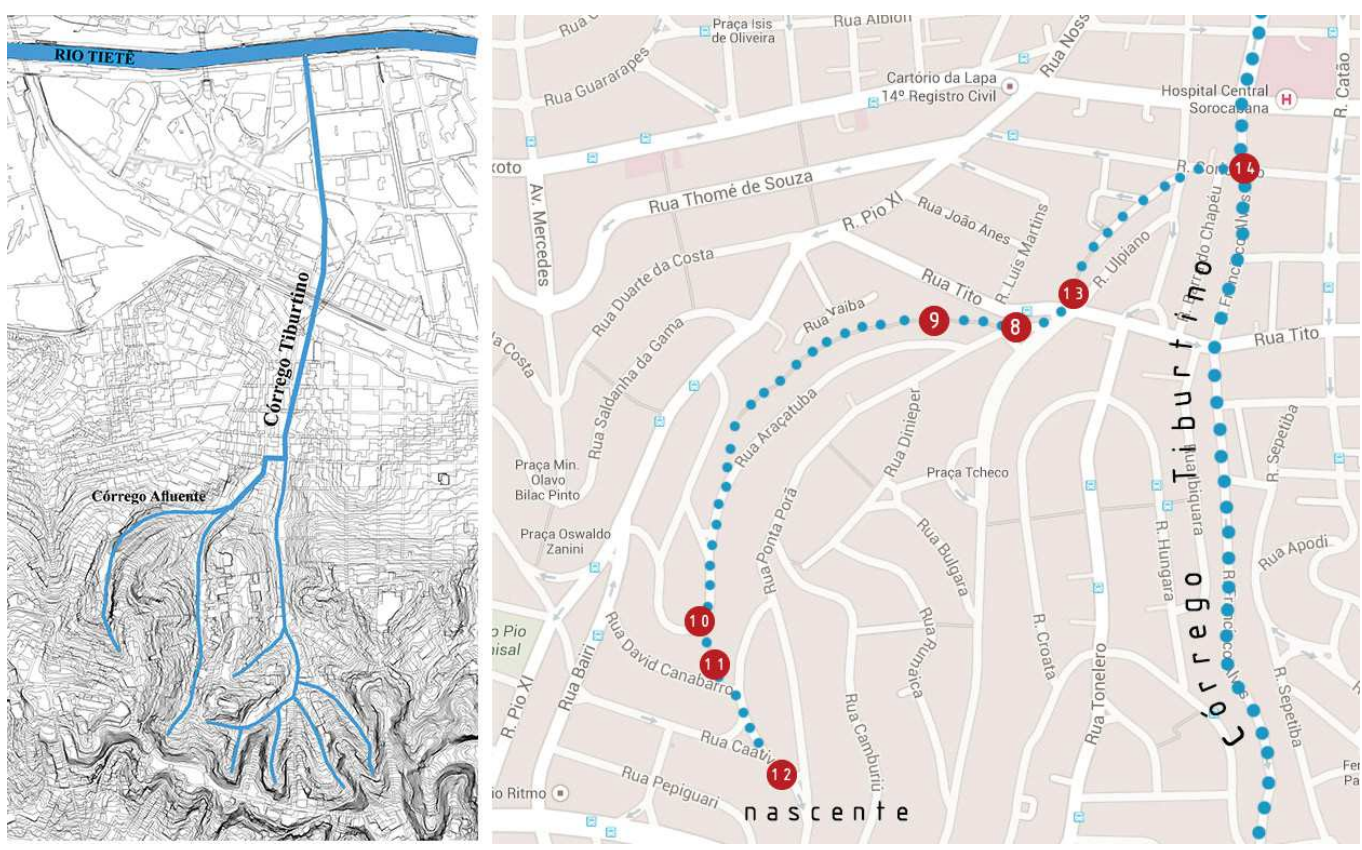

Figura 16 Córregos que compõem a bacia hidrográfica do Tiburtino.

Fonte: Elaborada por Murillo Aggio Piazzi, 2014, com base em levantamento topográfico oferecido pela Prefeitura de São Paulo, 2005/2006, e Google Maps, 2012.

\section{CONSIDERAÇÕES FINAIS}

É comum, em São Paulo, encontrarmos casos semelhantes ao relatado. De fato, hoje, praticamente toda a rede hídrica capilar da cidade encontra-se ocultada. Trazer os córregos novamente à tona é uma proposta ainda possível de ser concretizada em nossa realidade urbana. Não se defende aqui a volta do córrego ao seu estado natural; tal proposta seria praticamente irrealizável. No entanto, intervenções sutis, que pontuem o local da nascente de um córrego, sua foz ou alguns acidentes particulares do seu trajeto, não parecem requerer grandes esforços para serem implementadas.

Porém, tal raciocínio parece ir contra uma cultura que, como visto, sempre encarou os cursos d'água como barreiras à urbanização. Os córregos, desde o início do século XX, foram associados com a insalubridade. Os projetos urbanos frequentemente os colocaram em locais isolados, utilizando-os nos serviços de saneamento, quando não na rede de esgoto. Assim, foram ocultos, desaparecendo gradualmente da paisagem. 
A perpetuação dessa cultura significa, para os cidadãos, o desaparecimento de uma memória ligada aos córregos, de modo que as gerações futuras podem até mesmo não saber da existência da vasta rede hídrica que São Paulo possui.

Em última instância, a descrição do córrego e a recuperação da história de sua ocultação, pode trazer novamente à superfície aquilo que hoje só pode ser encontrado nas profundezas da cidade.

\section{REFERÊNCIAS BIBLIOGRÁFICAS}

AB'SÁBER, Aziz Nacib. Geomorfologia do sítio urbano de São Paulo. Edição Fac-similar - 50 anos. São Paulo: Ateliê Editorial, 2007.

ARQUIVO Aguirra. Documentação - Museu Paulista, Universidade de São Paulo - USP, Fichas do Subdistrito da Lapa.

CORREIO Paulistano, São Paulo, 31 out. 1903, p. 3. Disponível em: <http://memoria.bn.br/pdf/090972/ per090972_1903_14443.pdf>. Acesso em: 25 ago. 2017.

DIÁRIO Oficial do Estado de São Paulo, São Paulo, 14 jun. 1934, p. 5. Disponível em: <https://www. imprensaoficial.com.br/DO/BuscaDO2001Documento_11_4.aspx? link=/1934/ddiari\%2520oficial/junho/14/pag 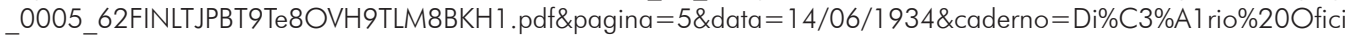 al\&paginaordenacao $=100005>$. Acesso em: 25 ago. 2017.

São Paulo, 12 out. 1948, p. 37. Disponível em: <https://www.imprensaoficial.com.br/DO/ BuscaDO2001Documento_11_4.aspx?link=/1948/eexecutiv/outubro/12/pag_0037_5HR2LOSQD8L5LeDCJ07I GOOCMTO.pdf\&pagina $=\overline{3} 7 \& \bar{d}$ ata $=12 / 10 / 1948 \&$ caderno $=$ Executivo\&paginaordenacao $=100037>$. Acesso em: 25 ago. 2017.

. São Paulo, 18 set. 1956, p. 67. Disponível em: <https://www.imprensaoficial.com.br/ DO/BuscaDO2001Documento_11_4.aspx?link=/1956/executivo/setembro/18/pag_0067_ D9MA82FE8F2EEe 10S0090S93UT5.pdf\&pagina=67\&data = 18/09/1956\&caderno= Executivo\&paginaordenac $\mathrm{ao}=100067>$. Acesso em: 25 ago. 2017.

JORGE, Janes. O rio que a cidade perdeu: o Tietê e os moradores de São Paulo, 1890-1940. São Paulo: Alameda, 2006.

KAWAI, Célia Seri. Os loteamentos de traçado orgânico realizados no município de São Paulo na primeira metade do século XX. 2000. 172 f. Dissertação (Mestrado em Geografia) - Faculdade de Filosofia, Letras e Ciências Humanas, Universidade de São Paulo, São Paulo, 2000.

MULTISPECTRAL. Geoportal. São Paulo: Multispectral Empresa Brasileira de Mapeamento e Aerofotogrametria, 2014. Disponível em: <http://www.geoportal.com.br/memoriapaulista/>. Acesso em: 25 ago. 2017.

PMSP/SMDU. Mapa Digital da Cidade de São Paulo. São Paulo: Prefeitura de São Paulo/Secretaria Municipal de Desenvolvimento Urbano, 2013. Disponível em: <http://geosampa.prefeitura.sp.gov.br/PaginasPublicas/_SBC. aspx>. Acesso em: 25 ago. 2017.

PONCIANO, Levino. Bairros paulistanos de A a Z. São Paulo: Senac, 2001.

PRADO JR., Caio. A cidade de São Paulo: geografia e história. 2 ed. São Paulo: Brasiliense, 1998.

SANTOS, Wanderley dos. Lapa. São Paulo, São Paulo: Departamento de Cultura, 1980.

SANTOS FILHO, Lycurgo de Castro. A febre amarela em Campinas 1889-1900. Campinas: Centro de Memória, Unicamp, 1996.

SANT'ANNA, Denise Bernuzzi de. Cidade das águas: usos de rios, córregos, bicas e chafarizes em São Paulo (1822-1901). São Paulo: Senac, 2007. 